\title{
Transport's historical, contemporary and future role in shaping urban development: re-evaluating Transit Oriented Development \\ Richard D. Knowles ${ }^{1 \& 3}$, Fiona Ferbrache ${ }^{2}$ and Alexandros Nikitas ${ }^{3}$
}

${ }^{1}$ School of Environment \& Life Sciences, University of Salford, UK; ${ }^{2}$ Keble College, University of Oxford, UK; ${ }^{3}$ Huddersfield Business School, University of Huddersfield, UK

\begin{abstract}
This paper reviews transport's historical role in shaping urban development since industrialisation. Previous definitions of Transit Oriented Development (TOD) starting in the late $20^{\text {th }}$ century are challenged. Three distinct eras of TOD are identified: from the mid-19th century to early $20^{\text {th }}$ century; Planned TOD in the mid-20 $0^{\text {th }}$ century; and TOD for urban regeneration and/or urban expansion since the late $20^{\text {th }}$ century, now featuring rail and bus rapid transit, cycling and walking, and automated transport. Future links with disruptive transport technologies are highlighted as themes must be examined for assisting TOD's further development. The authors make the case, using empirical evidence from selected TOD applications from around the world, that high frequency transit service is essential for successful contemporary and future planned TODs. TOD is then redefined for the $21^{\text {st }}$ century and best practice policy recommendations are made.
\end{abstract}

Keywords: Transit Oriented Development (TOD); Transit Frequency; Urban Regeneration; Urban Development; Rail and Bus Rapid Transit; Cycling and BikeSharing; Automated and Autonomous Transport; Mobility-as-a-Service

\section{Introduction}

It has long been recognised that transport enables and shapes urban spatial development (Knowles 2006). At the same time land use planning processes may have an impact on individual mobility (Zhao 2011). Urban land rent theory and location theory conceptualise the connection between transport and urban land use (Alonso 1964; Berry et al. 1963; Hansen 1959; Hartshorn 1992; Hoyt 1939). Investment in urban transport enhances accessibility, stimulates activity and increases the value of land close to transit stations and stops. Successive innovations in powering transport from horse drawn to steam, oil and electric driven, and in developing rail-based transport systems and later motorised road transport, all impacted on the shape and extent of urban development. Clark (1958) reviewed the impacts of waves of new transport technologies and called transport "a maker and breaker" of cities.

Historically, the development of horse drawn and then mechanised rail-based transport, as part of the industrial revolution, facilitated a seismic change from small compact walking cities to expanded star shaped cities following public transport routes (Adams 1970). Mass production and ownership of private cars from the 1920s in the United States (US), and later elsewhere, enabled both interstitial urban development between radial transport corridors and outward urban sprawl. In many countries, the introduction of urban planning 
subsequently restricted further sprawl, but the strength of planning controls varied considerably from minimal to intense. With mass car ownership, cities decentralised as access to Central Business Districts (CBDs) became more congested and automobility enabled economic activity to move increasingly towards more car accessible locations particularly near to suburban motorway junctions and orbital (ring) roads (Farber and Paez 2010; Moon 1991). Edge Cities, or Suburban Downtowns, became the new urban frontiers, particularly in countries with weak planning controls (Garreau 1991; Hartshorn 1992).

Transport infrastructure investments thus are of massive importance for city planning and can be a decisive apparatus for development. They are typically location specific and have potential effects on the pattern of local urban and economic growth (Banister and Berechman 2001). Although the term TransitOriented Development (TOD) was only developed by Calthorpe in the late 1980s and published in 1993, this paper provides evidence that the process he identified of focusing housing development, employment sites, facilities and services around stations, stops and junctions on transport routes dates back to the mid-19th century. It is the high accessibility of these sites that makes them attractive and profitable for urban development. Calthorpe (1993) identified three TOD characteristics: Density with high density of dwelling units, population, jobs and activity sites; Diversity with multiple forms of land use; and Design with dense urban grids and pedestrian friendly environments (Table 1). Cervero and Kockleman (1997), Curtis et al. (2009) and Ewing and Cervero (2010) then developed Calthorpe's definition by adding three more characteristics: Distance to access transit; Destination Accessibility; and Demand Management of urban car traffic. Knowles $(2012,2016)$ identified High Frequency transit services as a seventh requirement for successful TOD.

While the concept of TOD enjoys broad appeal, in truth the gulf between theory and practice remains huge (Cervero et al. 2002) due to procedural, economic, cultural and physical implementation challenges (Loukaitou-Sideris 2010). TODs are not easy to introduce and sustain (De Vos et al. 2014; Pojani and Stead 2014) thus the track record at implementing successful TODs has not been so far impressive (Loukaitou-Sideris 2000; Tan et al. 2014; Utter 2016). There is a need therefore to invest further effort at understanding how this can change in the future so that TOD is prioritised when it can be a viable option. Also, according to Hess and Lombardi (2004) the promise of TOD for increasing transit ridership, enhancing economic development, and establishing a "sense of place" at transportation nodes has been well documented in the literature (e.g. Cervero 2007; Lin and Shin 2008; Lund 2006; Papa and Bertolini 2015; Sung et al. 2011; Topalovic et al. 2012; Zamir et al. 2014) as well as policy instruments promoting its uptake (e.g. Guthrie and Fan 2016; Jacobson and Forsyth 2008; Singh et al. 2017; Tan et al. 2014). However, there was never a systematic effort dedicated to creating a chronological framework that identifies TOD's distinct phases of evolution from its very infancy to now and predict its transformation in the forthcoming decades that will be possibly defined by game-changing mobility technologies like automated public transport, Connected and Autonomous Vehicles (CAVs) and Mobility-as-a-Service (MaaS). This paper aims to address these critical research gaps. 


\section{Research Objectives and Structure}

More specifically, the research objectives of this paper are to identify: i) transport's historical, contemporary and future role in shaping urban development; ii) when and under what circumstances TOD can be identified; iii) a re-definition of TOD for the $21^{\text {st }}$ century and best practice policy recommendations.

The paper starts by re-examining Calthorpe's original 1993 definition of TOD and its refinement by Cervero, Curtis and others (Cervero and Kockleman 1997; Curtis et al. 2009; and Ewing and Cervero 2010). Evidence is synthesised to support that TOD is not a recent phenomenon but one with a rich history. The authors specifically identify three distinct eras of TOD dating from the mid-19th century through to today. The paper then examines, using selected examples, TOD modes and land use characteristics, whether the transit traffic is captive or has a choice, and the principal means of accessing transit. It then assesses the importance of transit service frequency and discusses the likely impacts of other complementary alternative forms of travel (e.g. bike-sharing) and gamechanging mobility paradigms (i.e. CAVs and MaaS) in successful contemporary and future planned TODs. Finally, TOD is redefined for the $21^{\text {st }}$ century and best practice policy recommendations are identified.

\section{Research Methodology}

This paper is the product of a systematic literature review that examined all the peer-reviewed TOD research literature published between 1993 and 2018 and a selection of important earlier research discussing relationships between transport and land use that came before TOD's first definition. Also, the work includes references to published work highlighting modes and trends of transport directly or indirectly reflecting and affecting TOD's past, current and future development.

A search in Scopus was undertaken using the term Transit Oriented Development and each author subsequently read 623 English language abstracts for the period 1993-2018 and generated an independent structured literature review looking to sum up TOD's course of development. Only journal papers and book chapters were assessed. The paper in its finalised form includes references to 137 studies all of them read from cover to cover. The selection of material was made, based on the relevancy of the resource for the paper's narrative, the host journal impact factor for the articles and each scholarly output's impact which can be interpreted by the number of its citations. The three authors then compared and synthesised their independent written outputs to create a single 'bigger-picture' narrative. While the authors acknowledge an element of subjective criteria in the choice of the material used for the present paper, this orderly methodological approach enabled them to minimise bias and improve the richness and quality of the content; the authors acted as checks and balances to each other and highlighted key points of the literature that a single author could have easily missed. 
To support their bibliographic work the authors reviewed evidence from a selection of representative international case study examples to recognise success or in some cases failure of TOD implementation and long-term viability practices. This adds to the paper's theoretical merits an empirical dimension that may directly inform policy-makers about some of the lessons available to them for maximising TOD's capacity for positive change.

While there are earlier literature reviews examining the many dimensions of TOD (e.g. Cervero et al. 2002; Dittmar and Poticha 2004; Hess and Lombardi 2004; Vessali 1996; Xu et al. 2017) and studies based on case study comparisons (e.g. Jacobson and Forsyth 2008; Millward 2006; Papa and Bertolini 2015; Searle et al. 2014; Thomas and Bertonlini 2014) our work offers to the state-of-the-art a unique point of reference. This is the development of a critical chronological framework that traces the process of TOD from the late 19th century (when this was at an embryonic stage and rarely recognised as a distinct urban fabric entity) to this very day and sets out trends of TOD's increasing role in the 21st century.

\section{Historic Role of TOD in Suburbanisation}

The earliest examples of TOD started in the mid-19th century with the development of suburban housing along new rail and tram (streetcar) routes in European and North American cities. The transit companies were privately owned, at least initially, and sometimes acted as real estate developers with the knowledge that house buyers or renters would provide captive traffic with no alternative means of accessing the city core's employment, retail and leisure activities (Table 2). Railway stations were spaced more widely than tram stops, with faster but lower frequency services, with walking as the access mode in both cases. TOD consisted of clusters of housing and sometimes with schools, local shops and factories.

There are numerous examples of $19^{\text {th }}$ century TOD in a range of countries. A careful selection of typical examples has been chosen here with a balanced geographical spread. In the UK, the Manchester South Junction Railway's branch to Altrincham in north Cheshire opened in 1849 with the specific purpose of developing commuter housing on cheap agricultural land for Manchester's more affluent factory owners and managers, away from the pollution and crime of the world's first industrial city. Although passenger traffic was captive and depended on access to the train services, Kellett $(1969,156)$ cautions that train frequencies were not high enough to encourage large commuter flows.

London was transformed by railway and tram development in the second half of the 19th century, more than doubling in area and population increasing to 6.5 million (Kellett 1969). In Birmingham, the Birmingham West Suburban Railway to Selly Oak, Bournville and Kings Norton was instrumental from 1871 in its suburban development, but by 1903 most local residents used cheaper and more frequent trams (Kellett 1969, 363). 
In Montréal, Canada rail service frequency was limited with several lines having only one train during peak periods. With low frequency train services, real estate development in the suburbs remained limited (Barrieau 2018).

Many cities and towns in Europe and North America developed 'streetcar suburbs' from the mid-19th century initially on horse-tram routes that were later electrified (Ward 1964; Warner 1978). Boston, Copenhagen, Glasgow and Leeds are classic examples of high-density TOD facilitated by high frequency and low fare trams. Flat fares in cities like Boston and Copenhagen removed the fare penalty, but not the travelling time penalty, from more distant suburbs. Vancouver and Los Angeles developed longer distance inter-urban tram routes (misleadingly called inter-urban railways) to neighbouring communities, facilitating the development of low to medium density intervening suburbs.

In this period, TOD was confined to economically developed countries. Some larger cities like London, Paris, Chicago and New York began to develop underground and/or elevated railways in their congested CBDs. London's Metropolitan Railway was the pioneer underground railway in 1863 and others followed from the 1890s (Hall 1988). Outside the CBD, surface transit routes with frequent services and cheap flat fares enabled large scale suburban TOD in New York and Chicago facilitating the development of Upper Manhattan, the Bronx and Brooklyn in New York and Chicago as the classic star-shaped city. To cite just one example of these early American TODs, Grand Central Terminal's construction in Manhattan, sparked terminal-adjacent and nearby construction of a constellation of hotels, office and apartment buildings, and clubs with "an overall urban form and uniform architectural style" that were appropriately called Terminal City (Renne and Listokin 2019). In London, the Metropolitan Railway promoted the development of 'Metroland' across Hertfordshire in the 1920s as a semi-rural idyll for commuters (Hall 1988).

\section{Planned mid-20 ${ }^{\text {th }}$ Century Rail TOD}

By the mid-20 $0^{\text {th }}$ century TOD had become less influential in urban development as privately-owned transit companies were becoming unprofitable, and many were taken over by city councils who saw transit as a means of personal mobility rather than as an urban development tool. Private car ownership was also growing quickly, especially in the US, so more urban residents had a choice of modes. Many towns and cities in developed countries, and especially in Britain and the US, then made the short-sighted decision to shut down their unprofitable tram systems, usually replacing them with more flexible but impermanent bus systems. Street based tram systems were sacrificed as they were seen as oldfashioned and obstructed the rapidly increasing number of private cars (Docherty et al. 2009).

Planned mid-20 th century rail TOD started in Denmark's capital Copenhagen just two years after the Second World War (Knowles 2012). It was seen as a tool to deliver large-scale suburban development along new or upgraded suburban rail transit routes to house a fast-expanding urban population, fuelled partly by substantial rural-urban migration as farm workers were replaced by mechanised agriculture. Car ownership was still very low and suburban residents provided 
captive traffic for rail transit. Planned TOD was also adopted for similar reasons in Oslo and Stockholm, the Norwegian and Swedish capitals, and later in Paris, the French capital (Table 3) (Fullerton and Knowles 1991). However Planned TOD was not widely adopted elsewhere by other European and North American cities. Instead most cities attempted to accommodate mass car ownership by trying to adapt the urban fabric to private car use. This was the rise of the 'automobile city' concept where cities began to decentralise and disperse (Newman and Kenworthy 1996). In contrast, some Asian cities later adopted Planned TOD and high-density urban development.

Copenhagen was the pioneer of Planned TOD with its 1947 Finger Plan (EgnsPlan) of five corridors (fingers) of planned urban development around stations, 'like beads on a string', on electrified suburban railway lines (Cervero 1998; Hansen 1960; Knowles 2012). Train services, with high frequencies of four per hour or more, provided mobility for residents and easy access to the CBD. When these five corridors in Copenhagen's advisory 1947 Finger Plan were fully developed by the early 1960s, the two corridors to the west and southwest were extended to accommodate further suburban development. Oslo's 1950 Comprehensive Plan, for Norway's capital, developed a pluri-nuclear city region underpinned by satellite towns on four new electrified suburban railway routes with high frequency train services (Fullerton and Knowles, 1991; Rasmussen 1965). Stockholm's 1952 General Plan, for Sweden's capital, created a three-tier hierarchy of centres with 18 neighbourhoods on four (later eight) electrified Tunnelbana rail routes with high frequency train services (Cervero 1998; Diem 1965; Fullerton and Knowles 1991). The design used pyramid housing density gradients falling away from each station and the A and B centres were larger with more jobs and activity sites.

Paris's 1965 Île-de-France Regional Masterplan developed five new towns along existing suburban rail routes and two new RER (Réseau Express Régional) commuter lines, all with high frequency train services. A new Business District was created at La Défense and the new Charles de Gaulle Airport was built as Paris's main airport.

In Asia, some cities that were growing rapidly from the 1960s saw Planned TOD as a way of providing high density suburbs, containing instead of allowing urban sprawl, whilst also supressing private car ownership and use through taxation and controls on car purchase. This was particularly important in small island city-states like Hong Kong and Singapore where land was at a premium. Singapore's 1971 Concept Plan was based on 20 new high-rise towns linked by a network of electrified suburban heavy rail services, subsequently supported by light rail feeders and car tolls to restrain car ownership and use (Cervero 1998). Tokyo and Hong Kong provide further examples of successful TOD with satellite towns linked by high frequency suburban or underground rail rapid transit services (Cervero 1998; Chow 2014; Loo et al. 2010).

All these cases of successful Planned TODs had mainly captive traffic, because of low car ownership, and high frequency rail transit services. TOD was less successful where rail transit services were not operational until after new 
housing was occupied, for example in the extended Køge Bay finger southwest of Copenhagen.

\section{Contemporary TOD for Urban Regeneration and Development}

While de-industrialisation, job loss and population decline impacted many cities and towns in heavy industrial regions ('Rustbelt' areas) by the 1980s and 1990s, not all cities and towns in economically developed countries experienced these impacts. For example, Sunbelt cities in the US were booming through this period, which is where most of the new US light rail systems were located (Messenger and Ewing, 1996). They provided an alternative to increasing car traffic and congested highways and encouraged the re-orientation of development away from sprawling, car-dependent suburbs to higher density, mixed use, multimodal urban centres (TODs). Part of the transition to developing a postindustrial economy has been the choice of whether to invest in new public transport systems. This led some cities in the developed world to adopt TOD as a key driver in urban regeneration. Recent research has recognised and understood the strong relationship between transport and urban regeneration, as well as new urban development (Banister and Berechman 2001; Knowles and Ferbrache 2016). TOD links new transport systems and urban planning. TOD is now no longer just based on heavy rail transit (HRT) systems but can be based on light rail transit (LRT), bus rapid transit (BRT) and cycling.

\section{i) Car Ownership, TOD and Urban Planning}

Rail transit and BRT face major challenges in contemporary cities in developed countries as widespread car availability means that most residents have a choice of mode for some or all journeys. High frequency, speed and capacity of a network of transit services are important to compete with the flexibility of car use.

The impacts of investment in light or heavy rail and bus rapid transit are enhanced by TOD, where planning policies and both private and public sector decisions focus investment in housing, employment, activity sites and public services around stations or stops. This is more difficult to achieve in a neo-liberal political environment where according to Gibbs (1997) market driven forces can conflict with urban sustainability objectives.

Supportive policies that discourage car use, such as limiting parking facilities and making them more expensive, have been employed alongside transport planning in some TODs (Willson 2005) to encourage modal shift onto public transport. Examples of such initiatives can be found in North America, for instance, in Boston and Ottawa (Vincent and Callaghan 2008). Introducing road pricing and toll cordon schemes has also discouraged car use and incentivised public transport use in a few cities including London, Oslo, Singapore and Stockholm. Other policies have called for the integration of public transit with cycling, walking and safe access to transit stations. As was found in Bangalore, India, without such integration and provision of alternative access, residents with cars can be difficult to capture as transit users (Chava et al. 2018). 
ii) Urban Regeneration, Sustainability and Smart Cities

Investment in new high frequency rail or bus rapid transit systems can facilitate both urban regeneration and new urban development in many ways. It enables: extension of labour market catchment areas; stimulation of inward investment; unlocking of previously hard to reach sites; reorganisation and rationalisation of production, distribution and land use; and the triggering of fresh growth (Knowles and Ferbrache 2016). City image and quality can also be enhanced by investment in new rapid transit systems, active transport and pedestrian friendly public spaces (Ferbrache and Knowles 2017; Ratner and Goez 2013). However, as land and property values rise with TOD, gentrification of housing can result in the displacement of poorer residents.

TOD encourages mixed land uses and concentrated activity sites, reduces the need and time to travel, and increases the proportion of trip destinations accessible by bike or walking. Cities become more sustainable if more trips are made by active transport (cycling and walking) and public transport, and fewer trips by cars, and these are all hallmarks of successful TOD.

TOD is also a very important part of a broader Smart Growth approach to urban development and regeneration in many countries (La Greca et al. 2011; Nahlik and Chester 2014; Renne 2008). The use of ICT (Information and Communication Technology) using mobile travel apps and electronic travel guides can provide real-time information on rail and bus schedules and journey times, traffic congestion, road works and accidents, weather conditions and alternative routes. Instant electronic communication also provides opportunities for telecommuting, conferencing, facetime, internet access, emails and social media which can all partially replace transport. On-line shopping also replaces many trips but adds delivery trips and vehicles. ICT can improve transport massively (Black and Van Geenhuizen 2006; Cohen-Blankshtain and Rotem-Mindali 2016) and thus directly and indirectly support successful TODs.

\section{iii) TOD and Rail Rapid Transit}

Most contemporary TODs are based on investment in new, high service frequency LRT or HRT systems for urban regeneration and/or new urban development (Table 4) (Knowles and Ferbrache 2016). These higher transit frequencies, with a minimum service level of three or more trains per hour, or five or more slower LRT trams or BRT services per hour, are essential to compete with cars, as most traffic is no longer captive, especially in European and North American cities. Larger transit capacity results from a combination of longer trains and higher service frequencies. Speed is also important as faster HRT creates a wider 60minute catchment area than slower LRT or BRT.

Representative examples of TOD and rail rapid transit are drawn from Europe, North America, Asia, South America and Australia.

\section{a) Dockland and Waterfront Regeneration}

Successful regeneration of brownfield former dockland, waterfront or industrial sites as TODs is widespread. A prime example is Canary Wharf TOD in London's Docklands, where the abandoned and derelict West India Docks were 
transformed from the end of the 1980s into a new major mixed-use private sector business and residential district after the new driverless Docklands Light Railway (DLR) unlocked this previously hard to reach brownfield area (Table 4) (Knowles and Ferbrache 2016). This stimulated new inward investment and enabled many businesses to relocate and expand from cramped sites in the City of London. Extension of the underground Jubilee Line HRT from central London through Canary Wharf to Stratford, and a network of new DLR routes, consolidated this very successful TOD (Jones et al. 2004). Canary Wharf's rail connections will improve further in 2020 when CrossRail (Elizabeth Line) will provide frequent higher speed connections from Heathrow Airport and Reading to the west, through central London and the City of London and eastwards to Shenfield and Abbeywood.

Salford Quays in the UK was re-developed as a mixed-used residential, office, retail and leisure site from the late 1980s on the site of the abandoned and derelict Manchester Docks at the head of the Manchester Ship Canal. Initial limited success was overcome by investing in an extension of Manchester's Metrolink LRT scheme partly funded by private sector developers. MediaCityUK was developed at a later date on the site of disused Dock 9 as a TOD focussed around another Metrolink extension and station. This facilitated the relocation of thousands of media jobs from parts of the BBC in London and Manchester and from other media companies (Knowles and Binder 2017).

Some other notable examples of dockland and/or waterfront regeneration linked to transit include Bordeaux, Copenhagen, Hong Kong, Oslo, Singapore, San Francisco's Fisherman's Wharf and Embarcadero, and Sydney.

\section{b) Urban Regeneration}

There is much evidence of other urban regeneration related to transit. A prime example is Grenoble in France, where high frequency street-based LRT was retrofitted alongside widespread pedestrianisation and green landscaping in the 1980s to help the city regenerate. This 'Grenoble Effect' helped to successfully rebrand and market the city and has been successfully copied by many other French towns and cities (Boquet 2017; Ferbrache and Knowles 2017).

In the US, the level of residential, office and commercial development in some transit-served central and downtown areas has been considerable and has changed overall development patterns in some metropolitan areas such as Portland, Oregon and Denver (Cervero et al. 2004; Goetz, 2019; Ratner and Goetz 2013; Schorung 2019). However weak planning powers have sometimes limited the success of TODs in cities such as Los Angeles, Sacramento and St Louis in the US and Sheffield and Sunderland in the UK (Knowles and Ferbrache 2014). LRT investment has often been retrofitted to assist regeneration in urban areas such as London Docklands, Salford Quays and Nottingham in the UK, Bordeaux, Grenoble and Rouen in France and Baltimore in the USA (Knowles and Ferbrache $2014,2016)$. The term Transit Adjucent Development (TAD) has also been employed in planning strategies revealing differential impacts (from TOD) on neighbourhood change (Miner et al. 2019). 
Vancouver's driverless SkyTrain, built largely on the disused route of its former inter-urban railway and a disused freight tunnel under its CBD, helped to regenerate inner city areas and facilitated the development of the new Burnaby business district and MetroTown shopping mall (Knowles and Ferbrache 2016).

\section{c) New Urban Development}

Contemporary rail-based TODs also include new high-density urban developments especially in several large Asian cities like Hong Kong, Seoul and Singapore (Table 4). In Hong Kong's case, its Transit \& Property Development Model uses the development gain from building new high-rise housing to pay for the HRT investment and subsidise its fares (Loo et al. 2010).

In Copenhagen, the development of Ørestad New Town was facilitated by a new LRT mini-metro from 2002 as a new 'finger' of mixed-use development on land reclaimed from the sea (Knowles 2012). The Danish Broadcasting Company DR Byen relocated here from numerous CBD sites, whilst Ferring Pharmaceuticals and Rambøll Engineering also rationalised their activities from different sites and relocated here. Ørestad's location en route to the Øresund Bridge's rail and motorway route to Sweden brings an added dimension to its TOD.

\section{iv) TOD and Bus Rapid Transit}

BRT is a hybrid form of urban passenger transport that brings together the flexibility and cost-effectiveness of buses with rail-like standards of service provision and rights of way (Ferbrache 2018, 2019; Nikitas and Karlsson 2015). BRT now provides an alternative transit mode for successful TOD for new build and urban regeneration (Cervero 1998; Cervero and Dai 2014; Cervero and Landis 1995; Currie 2006; Stokenberga 2014). However, Vincent and Callaghan (2008) reported that just eight per cent of US TOD initiatives were linked to BRT. The impermanence of BRT infrastructure "greatly increases the risk of investing in transit-supportive land-use development", therefore limiting TOD (California Department of Transportation, in Currie 2006).

Cervero (2013) suggests that BRT provides a TOD market niche for low-tomoderate density build. Examples of successful TOD based on BRT include Curitiba in Brazil, Brisbane in Australia and Ottawa in Canada (Table 4). Curitiba's success stems from a political commitment towards integration of BRT and a linear mixed-use development pattern built up around three parallel roads with the BRT corridor at its centre (Lindau et al 2010a, 2010b). Its mixed-use commercial and high-density residential development generates high BRT usage.

Ottawa's BRT has been "the transit anchor for the city's land use intensification strategies" (Vincent and Callaghan 2008, 58). Development focussed initially on commercial and retail activity around BRT stations and later on high-density residential building. Ottawa has also aimed to promote TOD and boost its ridership (as a percentage of motorised trips) by introducing supportive parking policies to discourage car use. Since the opening of BRT, the government have eliminated parking spaces at retail centres and for employees and have encouraged use of feeder bus services to access BRT stations by limiting the spatial provision of park-and-ride. Not only does this aim to create a more 
captive market for BRT but also makes space available for development rather than parking around stations closer to the CBD.

TOD in Brisbane developed around three BRT corridors, initially retrofitted on urban sites but subsequently on green-field sites and as urban infill including air rights development (Table 4) (Vincent and Callaghan 2008). This demonstrates that BRT can match the regeneration and urban development impacts of railbased TOD. Market investment has driven TOD in Brisbane rather than government funding.

BRT in Bogotá, Colombia, is an example where land use planning and transit investment were difficult to coordinate, exacerbated by this system being the first BRT service that the government had constructed (Lund et al. 2004). Development around stations demonstrates some land use change from agricultural to commercial development, and more intense construction of residential units including social housing provision (Vergel-Tovar and Camargo 2019).

\section{v) Active Transport and TOD}

Cycling and walking are major choices for shorter trips in mixed use TOD sites. Also, their role as the "last mile modes" between home and transit stations is a major factor influencing residents' usage of public transit systems (Zhao and Li 2017). Designing TOD with good walking-friendly access to stations is critical to its success and is associated with higher public transit ridership (Akbari et al. 2018). According to Schlossberg and Brown (2004) walkability is often the unspoken "making or breaking" component to TOD theory; thus pedestrian access and movement should be critical when implementing and evaluating TOD projects. Bicycle use is significantly associated with the built environment considerations (Zhao, 2014); where cycling thrives, TOD has the potential to thrive too. Cycling allows TOD users to travel three to five times longer access distances than walking and access a 25 times larger accessible area (Lee $e t$ al. 2016). Cycling and public transport need to develop a symbiotic relationship (Kager et al. 2016); cycling should not just function as a feeder mode for TOD but be an indispensable part of the travel experience when possible because according to Zhao and Li (2017) "bicycle + transit" has been a proven tool to reduce car use in transit station corridors. Cycling is therefore of increasing importance in TODs and bike use has grown with the development of dedicated cycling paths and bike parking and innovative bike-sharing schemes.

Bike-sharing, a hybrid travel mode with an exponential growth over the last decade across the world, has morphed into another possible pillar for TOD due to its power to provide flexible, affordable and sustainable first-mile and lastmile mobility solutions (Nikitas et al. 2016) Bike-sharing provides short-term access to locally branded bicycles on an 'as needed' basis that extends the reach of public transit services to final destinations and could be a door-opener for increased bicycle usage (Nikitas 2018). It can add another pro-environmental dimension to TOD if it prompts residents to stop using cars for distances beyond easy walking distance (Cervero and Sullivan 2011). It can also be a feeder service for trip origins and destinations within a central area especially for rail and bus 
services (Murphy and Usher 2015). Bike-sharing is now often GPS-based, and thus dockless, and can be accessed easily by mobile apps. Despite legitimate criticism about numerous failing schemes lately (e.g. de Chardon 2019) bikesharing may still be effective and attractive when it co-exists with extensive cycleway and bike path networks, bike parking facilities and cycling-friendly policies (Nikitas et al. 2019). Traditional cycling cities like Amsterdam, Copenhagen, Groningen and Stockholm, but also others like Paris and Barcelona which invested heavily in public bicycle programmes, are good examples of how cycling in general and bike-sharing in particular have become part of a greener and more multi-modal brand of TOD.

\section{vi) Automated and Autonomous transport and TOD}

LRT and HRT on segregated elevated, underground or surface routes have been pioneers in driverless, automated transport and benefit from much lower operating costs (Kellerman 2018). Automation is a key element in some TODs including Canary Wharf accessed by London's Docklands Light Railway, Ørestad accessed by Copenhagen Metro, MetroTown accessed by Vancouver's SkyTrain, and Singapore's CBD accessed by five HRT lines. Innovative developments of driverless buses and LRT vehicles for use in mixed on-street traffic will become important elements in TODs.

\section{vii) Gentrification effects of TOD including displacement}

Gentrification and displacement are concepts closely associated with contemporary forms of TOD and its effects on urban spaces and on people. Gentrification is "the production of space for - and consumption by - a more affluent and very different incoming population" (Slater et al. 2004, 1145) and can attract and provide valuable capital investment towards revitalisation of urban areas. Gentrification, however, can create processes of displacement through which lower-income inhabitants are pushed out of the areas they inhabit (or potentially wish to inhabit) through redevelopment projects and rising land and property values (Cervero and Kockelman 1997; Chava et al. 2018; Freeman and Braconi 2004; Kahn 2007; Rayle 2015; Zuk et al. 2018).

Urban land rent theory links improved accessibility from transport infrastructure investment to increasing land and property values (Alonso 1964). Zuk et al. $(2018,39)$ found that "heavy rail systems have a greater impact on property values than light rail systems. This is likely due to heavy rail's greater frequency, speed, and scope of service compared to most light rail networks". BRT's impacts are more limited as the fixed routes associated with rail transit infrastructure are more likely to encourage investment for development and increases in property prices (Ingvardson and Nielsen 2017; Pang and Jiao 2015; Rayle 2015).

TOD is often designed to attract middle and higher-income households, potentially for the higher property tax revenues they are likely to bring and acting as a marketing strategy for cities competing on a global stage for capital investment. Neoliberal goals for transport investment and urban restructuring are often favoured over, for example, improving societal goals (Grengs 2005; Rayle 2015). Paradoxically, less affluent residents are more likely to use and 
benefit from access to transit whilst higher-income residents in a gentrified TOD area are less inclined to use public transit as they are more likely to have access to private cars (Dong 2017; Jones and Ley 2016; Lucas and Jones 2012; Pucher and Renne 2003; Renne et al. 2016). Attracting lower-income residents into TOD areas through provision of affordable housing and social housing is recommended as a broader policy goal for future TODs (Chava et al. 2018).

\section{Future Urban Development and TOD}

TOD is now part of a broader sustainable and 'Smart Growth' approach to urban development (Goetz 2013; Knowles 2016) and is a city planning trend that will continue to emerge and diversify in years to come. The success of TOD can also be attributed to changing preferences for urban living with an increasing interest, especially amongst younger adult age groups, to live, work and socialise in TOD areas rather than live in low-density private car dependent areas.

\section{i) Cities embracing a TOD-oriented future}

Numerous cities in many countries, in all continents, are now planning future TODs to focus mixed-use urban development or regeneration around rail and/or bus rapid transit nodes.

For example, Delhi, Bengaluru and Ahmedabad in India are planning TODs around new metro rail stations or BRT (Joshi et al. 2017). In the Gulf, Qatar is planning a TOD at Al-Waab (Alattar and Furlan 2017) whilst Dubai is developing Jumeirah Central. Hong Kong is developing several TODs including Union Square in West Kowloon and LOHAS Park.

In New York City, Hudson Yards' mixed-use TOD links an extension to the No. 7 subway line to a 28-acre site created by utilising the air rights over a working rail yard near Pennsylvania Station. In Edmonton, Canada, TODs are planned at Glenora and Strathearn on future LRT routes.

In Denmark, following the development of Ørestad as Copenhagen's most recent TOD, redundant dockland in Nordhavn is now being redeveloped as a sustainable urban district with new neighbourhoods served by a light rail minimetro extension. Two stations at Nordhavn and Orientkaj will open in 2020 to serve this brownfield regeneration project with a further extension and three more stations under consideration (By og Havn 2018a). In May 2018, Price Waterhouse Coopers announced their decision to move 1500 employees from Hellerup to Nordhavn on a site near to the new Metro station and existing S train station (By og Havn 2018b).

However, a critical analysis of TOD proposals sometimes exposes a serious mismatch between TOD aspiration and reality. In the UK, the Government now requires local councils to quantify their future land needs for the next 20 to 25 years for housing, employment and other activities and identify the sites needed to deliver these targets. Greater Manchester Combined Authority's draft Greater Manchester Spatial Framework (GMCA: GMSF) for development sites up to 2040 has clear TOD objectives and environmental and sustainability objectives (GMCA 2016, 2019). However, of the 53 proposed GMSF strategic development sites, 31 
are dependent just on road access, 27 sites are located close to motorways and 26 to other major roads, and most are distant from light and heavy rail stations (GMCA 2019). Only 5 out of 53 sites already have high frequency light rail services within 800 metres walking distance, a further 12 have proposed light rail or tram-train services or new heavy rail stations and 5 have proposed BRT services. 39 out of the 53 sites are located wholly, and a further 9 sites partly, on previously protected Green Belt. The 2019 revised GMSF plan still contains no analysis of rail, light rail and bus rapid transit frequency and capacity whilst most heavy rail train services have low frequencies of two or less per hour, incompatible with TOD.

\section{ii) TOD and technology innovation}

The future of TOD will likely be also tied up with the rise of technology interventions that would be smarter than ever before and could be disruptive to the mobility provision as this is packaged today. TOD will also be linked with a universal approach to push for a transport paradigm transition that would be underpinned by the rules of a new connected, shared and digitised mobility ethos. Specific planning mechanisms and technology initiatives to facilitate TOD will be adopted to maximise the impact of investment in rapid transit and transport's role in shaping urban development. Some future directions for diversifying, modernising and revolutionising TOD include among others synergies with interventions such CAVs, MaaS and ICT.

\section{a) Connected and Autonomous Vehicles complement TOD}

We foresee that TOD would be significantly redefined by the adoption of a ground-breaking concept like Connected and Autonomous Vehicles (CAVs). CAVs will potentially complement the public transport provision in TODs, offering a door-to-door dimension that now most TOD applications lack, since they will most likely be shared and not private; although automobile manufacturers have not given up on the ownership model for them the evidence today seems to suggest that CAVs may operate predominately within car-sharing and ridesharing schemes as discussed in Nikitas et al. (2019) although automobile manufacturers have not given up on the ownership model for CAVs as yet and things may change. Urban planners need to pro-actively look for the formula that will allow them to eventually introduce CAVs as part of a homogeneous rapid transport system offered in TODs and not as a competitive and unsustainable alternative to this. In that respect, CAVs can be used as first and last-mile solutions and neighbourhood feeders to more mainstream mass transit-oriented systems. This in an uneasy union because of their traditionally contradictory roles so future planning efforts need to assist with balancing tensions and achieving beneficial outcomes.

\section{b) Mobility-as-a-Service creates TOD opportunities}

Mobility-as-a-Service (MaaS) is a new but rapidly emerging travel behaviour change initiative that aims to replace privately owned transport with personalised mobility packages (Nikitas et al. 2017). These give access to multiple travel modes on an as-needed basis through a powerful platform that exploits the riches of modern information and communication technologies. Fullscale MaaS systems in principle have to provide simultaneously an intermodal 
journey planner, a booking system, easy-payment and real-time information. TOD could be critical for the shift to a MaaS-oriented transport paradigm and vice versa since high frequency and easily accessible public transit services need to be the foundation on which MaaS should be built. TODs can in the short term serve as the most effective living labs for the implementation of newly established MaaS initiatives.

\section{c) TOD in the digital and information-centric era}

The transition to an even more ICT-centric era defined by an enhanced accessibility and availability of real-time digital information about every aspect of a public transport trip, interchange, ticket will solidify TOD operations. Not having enough information regarding routes and timetables, and thinking that public transport is difficult to use and information is difficult to access, has been a key reason for road users staying away from public transport services (Beirão and Cabral 2007) and therefore making TOD a less appealing investment for decisionmakers and investors. Future advancements in mobility information technology and provision are expected to minimise this problem especially when information is packaged within a holistic intervention like MaaS.

There are other future transport planning approaches that could advance the use of TODs like the much debated and still controversial Hyperloop and Unmanned Aerial Vehicle concepts. However, these may take many more years before they become operational on a mass scale. Another direction that is already becoming mainstream and could provide a future sustainability edge to TODs is the complete electrification of their transport services (especially if electromobility is generated by renewable energy sources) and the adoption of biofuels and other less polluting alternative fuelling methods.

As a whole, monolithic state or solely industry-led approaches cannot lead to success in such a complex and competitive context as smart urban mobility (Thomopoulos and Nikitas 2019). TODs would be an important determinant that could recalibrate future transport supply and demand only if it embraces technology innovation that is genuinely user-centric and flexible. One 'out-ofthe-box' approach to achieve this goal is by making the successors of current obstacles (i.e. private, conventionally fuelled and human-driven cars) complementary parts of their mass-transit systems.

\section{Conclusions}

The relationship of form, use, and density in urban development and their influence on travel and vice versa is a key element of many land use and transport policies (Olaru et al. 2011). TOD, a form of Neo-traditional development that constitutes the foundation of New Urbanism (i.e. a theoretical framework meaning to solve urban and neighborhood problems and bring about social change through physical design) is according to Sharifi (2016) a way to achieve smart growth. This paper recognises the importance of TOD as a dynamically evolving and when used wisely powerful tool for city-planners but much in line with Yang and Pojani (2017) acknowledges that TOD is not a panacea. However, it has a synergistic value greater than the sum of its parts as also noted by Duncan (2011) and thus can contribute positively in the creation of 
more livable urban futures. TOD needs supportive land use planning policies to be successful. TOD also now requires high frequency transit services as most traffic is no longer captive because many passengers have cars available as an alternative choice. Higher transit speeds widen the usual threshold of 60-minute travel time catchment areas, whilst increased capacity enables sustainable modes to increase modal share.

\section{A new definition of TOD for the $21^{\text {st }}$ century}

At a time when there is evidence that policy makers need to still better understand what is and what is not a TOD (Renne 2009) this paper introduces a new definition recognising the increasing complexity of the mobility paradigm that we live in.

Taking TOD forward in the 21st century requires continued recognition of the 6 Ds plus high frequency transit services that comprise successful TOD. In addition to this, it is now important to acknowledge that 'transit' encompasses the evolving range of transport modes around which urban development is concentrated. As explored here, these relate to, though are not restricted to, railbased transit of varying forms, BRT, walking, cycling and autonomous modes.

This evolving range of transport modes at the heart of TOD suggests a move towards increasingly sustainable urban planning in which urban growth requires simultaneous balance with more environmental, socially equitable goals, as well as smart growth strategies.

\section{Best Practice Policy Recommendations}

TOD's potential to embrace many contemporary urban issues can be enhanced through a set of best practice policy recommendations. These include:

- Specific planning mechanisms to facilitate TOD to maximise the impacts of investment in transit modes and transport's role in shaping urban development.

- Moving beyond integrated transport and urban planning as a basic starting point to include supportive policies that seek to discourage car use and attract a mix of socio-economic groups into TODs through development that can provide affordable housing or social housing for lower income families.

- Truly mixed forms of land use, which integrate residential with a range of commercial, leisure and employment sites that minimise the need to travel longer distances.

- Simultaneously promoting liveable cities based on attractive environments with aesthetic and open and green spaces.

- Fostering a symbiotic relationship between different transport modes (including walking, cycling and feeder services) that connect, rather than disconnect, and create a useable network of sustainable mobility forms.

- Integrating future transport developments with TOD including autonomous and connected transport, vehicle sharing hubs MaaS 


\section{Future Research Agenda}

This work did not only provide answers and useful lessons to city and transport planners by contextualising the course of TOD's development but also helps in stimulating and highlighting some critical research questions that remain unanswered. These are used as the epilogue of this study and formulate future research directions. How can city planners and mobility developers use more effectively the successful past TOD experiences as a compass for future development of the concept? Are there any more policies that can restrain a mobility paradigm that prioritises automobility over TOD? Can TOD inspire consistently travel behaviour change in a dynamically changing world? How TOD frequency and access can be improved in a cost-effective way? How TOD planners will respond to the challenges and opportunities underpinned by the disruptive concepts of MaaS and CAVs? Future research should address these knowledge gaps so that TOD can maximise its capacity to deliver more sustainable pathways to livable urban futures in cities looking to embrace winwin synergies between transport and land use planning.

\section{References}

Adams J.S. (1970) Residential structure of Midwestern cities. Annals of the Association of American Geographers, 60, 37-62

Akbari S., Mahmoud M.S., Shalaby A. and Habib K.M.N. (2018) Empirical models of transit demand with walk access/egress for planning transit oriented developments around commuter rail stations in the Greater Toronto and Hamilton Area. Journal of Transport Geography, 68, 1-8

Alattar D.A. and Furlan R. (2017) Urban regeneration in Qatar: A comprehensive planning strategy for the transport oriented development (TOD) of AlWaab. Journal of Urban Regeneration and Renewal, 9638 (1), 1-12

Alonso W. (1964) Location and land use. Harvard University Press: Cambridge MA

Banister D. and Berechman J. (2001) Transport investment and the promotion of economic growth. Journal of Transport Geography, 9, 209-218

Barrieau P. (2018) L'evolution des trains de banlieue montrealais: 170 ans de service (1847-2017). Doctoral thesis in urban studies. UQAM: Montreal, Canada

Beirão G. and Cabral J. S. (2007) Understanding attitudes towards public transport and private car: A qualitative study. Transport Policy, 14(6), 478-489

Berry B.J.L., Tennant R.J., Garner B.J. and Simmons J.W. (1963) Commercial structure and commercial blight. Research Paper 85. University of Chicago, Department of Geography: Chicago

Black, W. and Van Geenhuizen, M. (2006) ICT innovation and sustainability of the transport sector. European Journal of Transport and Infrastructure Research, 6(1), 39-60

Boquet Y. (2017) The renaissance of tramways and urban redevelopment in France. Miscellanea Geographica, 21(1), 5-18

By og Havn (2018a) Nordhavn development: 9 January 2018. Downloaded from website 20 July 2018

By og Havn (2018b) PwC moving from Hellerup to Nordhavn: 31 May 2018. 
Downloaded from website 20 July 2018

Calthorpe P. (1993) The Next American Metropolis: Ecology, Community and the American Dream. Princeton Architectural Press, USA

Cervero R. (1998) The Transit Metropolis: A Global Inquiry. Island Press: Washington DC

Cervero, R. (2007) Transit-oriented development's ridership bonus: a product of self-selection and public policies. Environment and Planning A, 39(9), 2068-2085

Cervero R. (2013) Bus rapid transit (BRT): an efficient and competitive mode of public transport. Working Paper 2013-01. Institute of Urban and Regional Development: Berkeley, California

Cervero R. and Dai D. (2014) BRT TOD: Leveraging transit oriented development with bus rapid transit investments. Transport Policy 36, 127-138

Cervero, R., Ferrell, C. and Murphy, S. (2002). Transit-oriented development and joint development in the United States: A literature review. TCRP research results digest, (52)

Cervero R. and Kockleman K. (1997) Travel demand and the 3 Ds: density, diversity and design. Transportation Research Part C: Transport and Environment, 2, 199-219

Cervero R. and Landis J. (1995) Twenty years of the Bay Area Rapid Transit system: Land use and development impacts. Transportation Research Part A: Policy and Practice, 31, 309-333

Cervero R., Murphy S., Ferrell C., Goguts N., Tsai Y-H., Arrington G.B., Boroski J., Smith-Heimer J., Golem R., Peninger P., Nakajima E., Chui E., Dunphy R., Myers M., McKay S. and Witenstein N. (2004) Transit-Oriented Development in the United States: Experiences, Challenges and Prospects. Transit Cooperative Research Program Report 102, Transportation Research Board: Washington DC.

Cervero R. and Sullivan C. (2011) Green TODs: marrying transit-oriented development and green urbanism. International Journal of Sustainable Development and World Ecology. 18(3), 210-218

Chava J., Newman P. and Tiwari R. (2018) Gentrification of station areas and its impact on transit ridership. Case Studies on Transport Policy, 6(1), 1-10

Chow, A. S. (2014) Urban design, transport sustainability and Residents' perceived sustainability: A case study of transit-oriented development in Hong Kong. Journal of Comparative Asian Development, 13(1), 73-104

Clark C. (1958) Transport - maker and breaker of cities. The Town Planning Review, 28(4), 237-250

Cohen-Blankshtain, G. and Rotem-Mindali, O. (2016) Key research themes on ICT and sustainable urban mobility. International Journal of Sustainable Transportation, 10(1), 9-17

Currie G. (2006) Bus transit oriented development - strengths and challenges relative to rail. Journal of Public Transportation 9:1-21

Currie, G. and Delbosc, A. 2014. Assessing Bus Rapid Transit system performance in Australasia. Research in Transportation Economics 48:142-151

Curtis C., Renne J.L. and Bertolini L. (2009) Transit Oriented Development: Making It Happen. Ashgate: UK 
de Chardon, C. M. (2019) The contradictions of bike-share benefits, purposes and outcomes. Transportation Research Part A: Policy and Practice, 121, 401419

Diem A. (1965) An alternative to unplanned urban growth: the case of Stockholm. Canadian Geographer IX (4), 193-204

Dittmar, H. and Poticha, S. (2004) Defining transit-oriented development: The new regional building block. In the: The New Transit Town: Best Practices in Transit-Oriented Development, pp. 19-40

Docherty I., Shaw J., Knowles R., and Mackinnon D. (2009) Connecting for competitiveness: future transport in UK city regions. Public Money and Management, 29(5), 321-328

Dong H. (2017) If You Build Rail Transit in Suburbs, Will Development Come? Journal of the American Planning Association, 82(4), 316-326

Duncan, M. (2011) The impact of transit-oriented development on housing prices in San Diego, CA. Urban Studies, 48(1), 101-127.

Ewing R. and Cervero R. (2010) Travel and the Built Environment: A MetaAnalysis. Journal of the American Planning Association, 76(3), 265-294

Farber S. and Paez A. (2010) Running to stay in place: the time-use implications of automobile oriented land-use and travel. Journal of Transport Geography, 19(4), 782-793

Ferbrache F. (2018) Developing bus rapid transit. Journal of Transport Geography 70, 203-205

Ferbrache F. (ed) (2019) Developing Bus Rapid Transit: The Value of BRT in Urban Spaces. Edward Elgar: Cheltenham, UK

Ferbrache F. and Knowles R.D. (2017) City boosterism and place-making with light rail transit. Geoforum, 80, 103-113

Freeman L. and Braconi F. (2004) Gentrification and displacement. Journal of the American Planning Association, 70(1), 39-52

Fullerton B. and Knowles R.D. (1991) Scandinavia. Paul Chapman Publishing: London

Garreau J. (1991) Edge City: Life on the New Frontier. Doubleday: New York

Gibbs, D. (1997) Urban sustainability and economic development in the United Kingdom: exploring the contradictions. Cities, 14(4), 203-208

Global BRTData (2016), Global BRT Data, accessed 15 June 2018 at www.brtdata.org

GMCA (2016) Draft Greater Manchester Spatial Framework: Draft for Consultation October 2016. GMCA: Manchester, UK

GMCA (2019) Greater Manchester's Plan for Homes, Jobs and the Environment: Greater Manchester Spatial Framework Revised Draft January 2019. GMCA: Manchester, UK

Guthrie, A. and Fan, Y. (2016) Developers' perspectives on transit-oriented development. Transport Policy, 51, 103-114.

Goetz A. (2013) Sustainable sprawl or urban centres: tensions and contradictions of smart growth approaches in Denver, Colorado. Urban Studies 50(11), 2178-2195

Goetz A. (2019) Effects of transit oriented development in Denver, Colorado. Chapter 7, 96-117 in Knowles R.D. and Ferbrache F. (eds) Transit Oriented Development and Sustainable Cities: Economics, Community and Methods. Edward Elgar Publishing: Cheltenham, UK and 
Northampton, MA, USA

Grengs J. (2005) The abandoned social goals of public transit in the neoliberal city of the USA. City, 9, 51-66

Hall P. (1988) Cities of Tomorrow: An Intellectual; History of Urban Planning and Design Since 1880. Blackwell: Oxford

Hansen V. (1960) Some characteristics of a growing suburban region. Geografisk Tidsskrift, 59, 214-225

Hansen W.G. (1959) How accessibility shapes land use. Journal of the American Institute of Planning, 25, 73-76

Hartshorn T.A. (1992) Interpreting the City. Wiley: New York

Hess, D. B., and Lombardi, P. A. (2004). Policy support for and barriers to transitoriented development in the inner city: Literature review. Transportation Research Record, 1887(1), 26-33

Hoyt H. (1939) The Structure and Growth of Residential Neighbourhoods in American Cities. Federal Housing Administration: Washington DC

Ingvardsen J.B. and Nielsen O.A. (2017) Effects of new bus and rail rapid transit systems - an international review. Transport Reviews, 38(1), 96-116

Jacobson, J. and Forsyth, A. (2008). Seven American TODs: Good practices for urban design in transit-oriented development projects. Journal of Transport and Land Use, 1(2), 51-88

Jones C.E. and Ley D. (2016) Transit-oriented development and gentrification along Metro Vancouver's low-income SkyTrain corridor. Canadian Geographer, 60(1), 9-22

Jones P., Eyers T., Georgeson N., Powell T., Paris J. and Lane R. (2004) The Jubilee Line Extension Impact Study: Main Findings and Lessons Learnt. Transport Studies Group Publication TSG 2004/36, University College London

Joshi R., Joseph Y., Patel K. and Darji V. (2017) TOD Lessons from Indian Experience. Working Paper 36. Centre for Urban Equity, CEPT University, Ahmedabad, India

Kager R., Bertolini L. and Te Brommelstroet M. (2016) Characterisation of and reflections on the synergy of bicycles and public transport.

Transportation Research Record Part A: Policy and Practice. 85, 208-219

Kahn M.E. (2007) Gentrification trends in new transit-oriented communities: evidence from 14 cities that expanded and built transit systems. Real Estate Economics, 35, 155-182

Keeney R. (2018) Personal communication $5^{\text {th }}$ August, based on Denver Tramways research, University of Denver, USA

Kellerman A. (2018) Automated and Autonomous Spatial Mobilities. Edward Elgar Publishing: Cheltenham, UK

Kellett J.R. (1969) The impact of railways on Victorian Cities. Routledge \& Kegan Paul: London

Knowles R.D. (2000) Light rail transit's impacts in British and Canadian cities. Association of American Geographers Annual Meeting: Pittsburgh, USA, $6^{\text {th }}$ April

Knowles R.D. (2006) Transport shaping space: differential collapse in timespace. Journal of Transport Geography, 14, 407-425

Knowles R.D. (2012) Transit Oriented Development in Copenhagen, Denmark: from the Finger Plan to Ørestad. Journal of Transport Geography, 22(1), 251-261 
Knowles R.D. (2016) OURSUS: Transport Geographers: ideas and experiences about aspects of sustainable cities. International Geographical Congress: Beijing, 22 $2^{\text {nd }}$ August

Knowles R.D. and Binder A. (2017) MediaCityUk: A Sustainable Transit-Oriented Development. Chapter 1, 3-12 in Theakstone W. (ed) Manchester Geographies. Manchester Geographical Society: Manchester, UK

Knowles R.D. and Ferbrache F. (2014) An Investigation into the Economic Impacts on Cities of Investment in Light Rail Systems. Report for UKTram: Birmingham, UK

Knowles R.D. and Ferbrache F. (2016) Evaluation of the wider economic impacts of light rail investment on cities. Journal of Transport Geography, 54, 430-439

La Greca, P., Barbarossa, L., Ignaccolo, M., Inturri, G. and Martinico, F. (2011) The density dilemma. A proposal for introducing smart growth principles in a sprawling settlement within Catania Metropolitan Area. Cities, 28(6), 527535

Lee J., Choi K. and Leem Y. (2016) Bicycle-based transit-oriented development as an alternative to overcome the criticisms of the conventional transit-oriented development. International Journal of Sustainable Transportation. 10(10), 975-984

Lin, J. J. and Shin, T. Y. (2008) Does transit-oriented development affect metro ridership? Evidence from Taipei, Taiwan. Transportation Research Record, 2063(1), 149-158

Lindau L.A., Hidalgo D. and Facchini D. (2010a) Bus rapid transit in Curitiba, Brazil. A look at the outcome after 35 years of bus-oriented development. Transportation Research Record 2193, 17-27

Lindau L.A., Hildago D. and Facchini D. (2010b) Curitiba, the cradle of bus rapid transit. Built Environment 36(3), 274-282

Loo B.P.Y., Chen C. and Chan E.T.H. (2010) Rail-based transit-oriented Development: lessons from New York City and Hong Kong. Landscape and Urban Planning, 97, 202-212

Loukaitou-Sideris, A. (2000). Transit-oriented development in the inner city: A Delphi survey. Journal of Public Transportation, 3(2), 5

Loukaitou-Sideris, A. (2010) A new-found popularity for transit-oriented developments? Lessons from Southern California. Journal of Urban Design, 15(1), 49-68

Lucas K. and Jones P. (2012) Social Impacts and Equity Issues in Transport: An Introduction. Journal of Transport Geography, 21, 1-3

Lund, H. (2006) Reasons for living in a transit-oriented development, and associated transit use. Journal of the American Planning Association, 72(3), 357-366.

Lund H., Cervero R. and Wilson R. (2004) Travel characteristicsof Transit-Oriented Development in California. Caltrans: Sacramento, California

Messenger, T. and Ewing, R. (1996) Transit-oriented development in the sun belt. Transportation Research Record, 1552(1), 145-153

Millward, H. (2006) Urban containment strategies: A case-study appraisal of plans and policies in Japanese, British, and Canadian cities. Land Use Policy, 23(4), 473-485

Miner A., Delmelle E.C. and Nilsson I. (2019) Chapter 8, 119-135 in Knowles R.D. and Ferbrache F. (eds) Transit Oriented Development and Sustainable Cities: Economics, Community and Methods. Edward Elgar 
Publishing: Cheltenham, UK and Northampton, MA, USA

Moon H. (1991) The interstate highway system. 425-427 in Janelle D.G. (ed) Geographical Snapshots of North America. The Guilford Press: New York and London

Murphy E. and Usher J. (2015) The role of bike-sharing in the city: Analysis of the Irish experience. International Journal of Sustainable Transportation. 9(2), 116-125

Nahlik, M. J. and Chester, M. V. (2014) Transit-oriented smart growth can reduce life-cycle environmental impacts and household costs in Los Angeles. Transport Policy, 35, 21-30

Newman, P. W. and Kenworthy, J. R. (1996) The land use-transport connection: An overview. Land Use Policy, 13(1), 1-22

Nikitas A. (2018) Understanding bike-sharing acceptability and expected usage patterns in the context of a small city novel to the concept: A story of 'Greek Drama'. Transportation Research Part F: Traffic Psychology and Behaviour, 56, 306-321

Nikitas, A. (2019) How to Save Bike-Sharing: An Evidence-Based Survival Toolkit for Policy-Makers and Mobility Providers. Sustainability, 11(11), 3206.

Nikitas A., Kougias I., Alyavina E. and Njoya Tchouamou E. (2017) How Can Autonomous and Connected Vehicles, Electromobility, BRT, Hyperloop, Shared Use Mobility and Mobility-As-A-Service Shape Transport Futures for the Context of Smart cities? Urban Science, 194), 36

Nikitas A. and Karlsson M. (2015) A worldwide state-of-the-art analysis for bus rapid transit: Looking for the success formula. Journal of Public Transportation, 18(1), 1-33

Nikitas A., Njoya E. T., \& Dani S. (2019). Examining the myths of connected and autonomous vehicles: analysing the pathway to a driverless mobility paradigm. International Journal of Automotive Technology and Management, 19(1-2), 10-30.

Nikitas A., Wallgren P. and Rexfelt O. (2016) The paradox of public acceptance of bike sharing in Gothenburg. Proceedings of the Institution of Civil Engineers - Engineering Sustainability 169(3), 101-113

Olaru, D., Smith, B. and Taplin, J. H. (2011) Residential location and transitoriented development in a new rail corridor. Transportation Research Part A: Policy and Practice, 45(3), 219-237

Pang H. and Jiao J. (2015) Impacts on Beijing bus rapid transit on pre-owned home values. Journal of Public Transportation, 18(2), 34-44

Papa, E. and Bertolini, L. (2015) Accessibility and transit-oriented development in European metropolitan areas. Journal of Transport Geography, 47, 7083

Pojani, D. and Stead, D. (2014) Ideas, interests, and institutions: explaining Dutch transit-oriented development challenges. Environment and Planning A, 46(10), 2401-2418

Pucher J. and Renne J.L. (2003) Socioeconomics of Urban Travel Evidence from the 2001 National Household Travel Survey. Transportation Quarterly, $57(3), 49-77$

Ratner, K. A. and Goetz, A. R. (2013) The reshaping of land use and urban form in Denver through transit-oriented development. Cities, 30, 31-46

Rasmussen T.F. (1965) The development of a planned plurinuclear city region: 
Greater Oslo. Regional Science Association Papers, XV1, Cracow Congress, Poland

Rayle L. (2015) Investigating the Connection Between Transit-Oriented Development and Displacement: Four Hypotheses. Housing Policy Debate, 25(3), 531-548

Renne, J. L. (2008) Smart growth and transit-oriented development at the state level: Lessons from California, New Jersey, and Western Australia. Journal of Public Transportation, 77

Renne, J. L. (2009) From transit-adjacent to transit-oriented development. Local Environment, 14(1), 1-15

Renne, J. L. and Listokin, D. (2019) The opportunities and tensions of historic preservation and transit oriented development (TOD). Cities, 90, 249-262

Renne J.L., Tolford T., Hamidi S. and Ewing R. (2016) The cost and affordability paradox of transit-oriented development: a comparison of housing and transportation costs across transit-oriented development, hybrid and transit-adjacent development station typologies. Housing Policy Debate, 26(34-5), 819-834

Schlossberg, M. and Brown, N. (2004) Comparing transit-oriented development sites by walkability indicators. Transportation Research Record, 1887(1), 34-42

Schorung M. (2019) New stations and transit oriented development in three United States rail corridors. Chapter 2, 12-28 in Knowles R.D. and Ferbrache F. (eds) Transit Oriented Development and Sustainable Cities: Economics, Community and Methods. Edward Elgar Publishing: Cheltenham, UK and Northampton, MA, USA

Searle, G., Darchen, S. and Huston, S. (2014) Positive and negative factors for transit oriented development: Case studies from Brisbane, Melbourne and Sydney. Urban Policy and Research, 32(4), 437-457

Sharifi, A. (2016) From Garden City to Eco-urbanism: The quest for sustainable neighborhood development. Sustainable Cities and Society, 20, 1-16

Singh, Y. J., Lukman, A., Flacke, J., Zuidgeest, M. and Van Maarseveen, M. F. A. M. (2017) Measuring TOD around transit nodes-Towards TOD policy. Transport Policy, 56, 96-111

Slater T., Curran W. and Lees L. (2004) Gentrification Research: new directions and critical scholarship. Special Issue of Environment and Planning $A$, 36(7), 1141-1150

Stokenberga A. (2014) Does bus rapid transit influence urban land development and property values? : a review of the literature. Transport Reviews 34(3), 276-296

Sung, H. and Oh, J. T. (2011). Transit-oriented development in a high-density city: Identifying its association with transit ridership in Seoul, Korea. Cities, 28(1), 70-82

Tan, W. G., Janssen-Jansen, L. B. and Bertolini, L. (2014) The role of incentives in implementing successful transit-oriented development strategies. Urban Policy and Research, 32(1), 33-51

Thomas, R. and Bertolini, L. (2014) Beyond the case study dilemma in urban planning: using a meta-matrix to distil critical success factors in transitoriented development. Urban Policy and Research, 32(2), 219-237.

Thomopoulos N. and Nikitas A. (2019). Editorial: Smart urban mobility 
futures. International Journal of Automotive Technology and

Management, 19(1-2), 1-9

Topalovic, P., Carter, J., Topalovic, M., \& Krantzberg, G. (2012) Light rail transit in Hamilton: Health, environmental and economic impact analysis. Social Indicators Research, 108(2), 329-350

Utter, M. A. (2016) Developing TOD in America: The private sector view. In Transit Oriented Development (pp. 229-244). Routledge.

Vergel-Tovar, C.E. and Camargo, W. (2019) Urban development impacts of bus rapid transit in Colombia: challenges and opportunities. In Ferbrache, F. (ed) Developing Bus Rapid Transit: The Value of BRT in Urban Spaces. Cheltenham: Edward Elgar

Vessali, K. V. (1996) Land use impacts of rapid transit: A review of the empirical literature. Berkeley Planning Journal, 11(1)

Vincent W. and Callaghan J.L. (2008) Bus rapid transit and transit oriented development: case studies on transit oriented development around bus rapid transit systems in North America. Breakthrough Technologies Institute: Washington DC

Ward D. (1964) A comparative historical geography of streetcar suburbs in Boston, Massachusetts and Leeds, England: 1850-1920. Annals of the Association of American Geographers, 54, 477-489

Warner S.B. Jr. (1978) Streetcar Suburbs: The Process of Growth in Boston, 1870-1900. 2nd Edition. Harvard University Press: Cambridge MA

Willson, R. (2005) Parking policy for transit-oriented development: lessons for cities, transit agencies, and developers. Journal of Public Transportation, $8(5), 5$

Xu, W. A., Guthrie, A., Fan, Y. and Li, Y. (2017) Transit-oriented development: Literature review and evaluation of TOD potential across 50 Chinese cities. Journal of Transport and Land Use, 10(1)

Yang, K. and Pojani, D. (2017) A decade of transit oriented development policies in Brisbane, Australia: Development and land-use impacts. Urban Policy and Research, 35(3), 347-362

Zamir, K. R., Nasri, A., Baghaei, B., Mahapatra, S. and Zhang, L. (2014) Effects of transit-oriented development on trip generation, distribution, and mode share in Washington, DC, and Baltimore, Maryland. Transportation Research Record, 2413(1), 45-53

Zhao, P. (2011) Car use, commuting and urban form in a rapidly growing city: Evidence from Beijing. Transportation Planning and Technology, 34(6), 509-527

Zhao, P. (2014) The impact of the built environment on bicycle commuting: Evidence from Beijing. Urban studies, 51(5), 1019-1037

Zhao, P. and Li, S. (2017) Bicycle-metro integration in a growing city: The determinants of cycling as a transfer mode in metro station areas in Beijing. Transportation Research Part A: Policy and Practice, 99, 46-60

Zuk M., Bierbaum A.H., Chapple K., Gorska K. and Loukaitou-Sideris A. (2018) Gentrification, displacement and the role of public investment. Journal of Planning Literature, 33(1), 31-44. 


\section{Table 1: Key Characteristics and Planning Elements of Successful}

\section{Transit-Oriented Development}

1. Density: high density of dwelling units, population, jobs and activity sites

2. Diversity: multiple forms of land use

3. Design: dense urban grids and pedestrian friendly

4. Distance to transit stations and stops: thresholds for walking

5. Destination accessibility: thresholds for walking

6. Demand management of road transport

7. High Frequency, Speed and Capacity of peak and off-peak heavy rail, light rail and/or bus rapid transit services

Sources: Calthorpe 1993; Cervero and Kockleman 1997; Curtis et al 2009;

Ewing and Cervero 2010; Knowles 2012 \& 2016

\section{Table 2: Historic Transit-Oriented Development}

\begin{tabular}{|c|c|c|c|c|}
\hline Examples & $\underline{\text { Mode }}$ & $\frac{\text { Captive }}{\text { Traffic }}$ & $\underline{\text { Access }}$ & $\begin{array}{c}\text { Land Use } \\
\underline{\text { Characteristics }}\end{array}$ \\
\hline $\begin{array}{l}\text { Altrincham } \\
\text { Birmingham } \\
\text { London }\end{array}$ & Suburban Rail & Yes & Walk & Clustered Housing \\
\hline Montréal & Suburban Rail & Yes & Walk & Clustered Housing \\
\hline $\begin{array}{l}\text { Boston, Denver } \\
\text { Copenhagen } \\
\text { Glasgow, Leeds }\end{array}$ & Tram/Streetcar & Yes & Short walk & $\begin{array}{l}\text { High Density } \\
\text { Housing, Jobs \& } \\
\text { Activity Sites }\end{array}$ \\
\hline $\begin{array}{l}\text { Chicago } \\
\text { London, } \\
\text { New York, Paris }\end{array}$ & $\begin{array}{l}\text { Subway in CBD } \\
\text { then surface HRT }\end{array}$ & Yes & Walk & $\begin{array}{l}\text { High Density } \\
\text { Housing, Jobs \& } \\
\text { Activity Sites }\end{array}$ \\
\hline
\end{tabular}




\section{Table 3: Planned mid 20th Century Transit-Oriented Development}

\begin{tabular}{|c|c|c|c|c|}
\hline City \& Plan & $\underline{\text { Mode }}$ & $\frac{\text { Captive }}{\underline{\text { Traffic }}}$ & $\underline{\text { Access }}$ & $\begin{array}{l}\underline{\text { Land Use }} \\
\underline{\text { Characteristics }}\end{array}$ \\
\hline $\begin{array}{l}\text { Copenhagen } 1947 \\
\text { Finger Plan }\end{array}$ & $\mathrm{S}$ train HRT & Yes & $\begin{array}{l}\text { Bike \& } \\
\text { Walk }\end{array}$ & $\begin{array}{l}\text { High Density Housing } \\
\text { \& Activity Sites }\end{array}$ \\
\hline $\begin{array}{l}\text { Oslo } 1950 \\
\text { Comprehensive } \\
\text { Plan }\end{array}$ & $\mathrm{T}$ train HRT & Yes & Walk & $\begin{array}{l}\text { High Density Housing } \\
\text { \& Activity Sites }\end{array}$ \\
\hline $\begin{array}{l}\text { Stockholm } 1952 \\
\text { General Plan }\end{array}$ & Tunnelbana HRT & Yes & $\begin{array}{l}\text { Walk \& } \\
\text { Bike }\end{array}$ & $\begin{array}{l}3 \text { tiers of centres } \\
18 \text { neighbourhoods } \\
4 \text { (later } 8 \text { ) T rail routes } \\
\text { Pyramid Density Gradients } \\
\text { Housing \& Activity Sites }\end{array}$ \\
\hline $\begin{array}{l}\text { Paris } 1965 \\
\text { Ile de France } \\
\text { Regional Masterplan }\end{array}$ & $\begin{array}{l}\text { HRT S train \& } \\
2 \text { RER }\end{array}$ & $\begin{array}{l}\text { Mostly } \\
\text { Captive }\end{array}$ & $\begin{array}{l}\text { Walk \& } \\
\text { Bus }\end{array}$ & $\begin{array}{l}5 \text { New Towns } \\
\text { La Defense Business District } \\
\text { Charles de Gaulle Airport }\end{array}$ \\
\hline $\begin{array}{l}\text { Singapore's } 1971 \\
\text { Concept Plan }\end{array}$ & HRT & $\begin{array}{l}\text { Mostly } \\
\text { Captive }\end{array}$ & $\begin{array}{l}\text { Walk } \\
\text { Bus/LRT }\end{array}$ & $\begin{array}{l}20 \text { New Towns } \\
\text { Car tolls }\end{array}$ \\
\hline
\end{tabular}

HRT- Heavy Rail Rapid Transit; LRT - Light Rail Transit; RER (Réseau Express Régional)

Sources: Cervero 1998; Fullerton and Knowles 1991; 


\section{Table 4: Contemporary TOD for Urban Regeneration and New Development}

\begin{tabular}{|c|c|c|c|c|}
\hline City \& Plan & Mode & $\begin{array}{l}\underline{\text { Captive }} \\
\underline{\text { Traffic }}\end{array}$ & $\underline{\text { Access }}$ & $\begin{array}{l}\text { Land Use } \\
\text { Characteristics }\end{array}$ \\
\hline \multicolumn{5}{|l|}{ REGENERATION } \\
\hline \multicolumn{5}{|l|}{$\overline{\text { Canary Wharf }}$} \\
\hline London UK & HRT & & Bus & Mixed Use \\
\hline \multirow{3}{*}{$\begin{array}{l}\text { Grenoble \& other } \\
\text { French cities }\end{array}$} & LRT & Part & Walk, & Retrofitted. \\
\hline & & & Bike, Bus & Mixed use \\
\hline & & & Metro & \\
\hline \multirow{2}{*}{$\begin{array}{l}\text { Portland, Denver } \\
\& 14 \text { other US Cities }\end{array}$} & LRT & Small & Car, Bike & Mainly Retrofitted \\
\hline & & part & Bus, Walk & Mixed Use \\
\hline \multirow{2}{*}{$\begin{array}{l}\text { Salford Quays } \\
\text { MediaCityUK }\end{array}$} & LRT & Part & Walk, Bike & Brownfield \\
\hline & & & Bus, HRT & Mixed Use \\
\hline \multirow[t]{2}{*}{ Vancouver, Canada } & LRT & Small & Car & Partly Brownfield \\
\hline & & part & Bus, Walk & Mixed Use \\
\hline
\end{tabular}

\section{NEW URBAN DEVELOPMENT}

\begin{tabular}{|c|c|c|c|c|}
\hline $\begin{array}{l}\text { Brisbane } \\
\text { Australia }\end{array}$ & BRT & $\begin{array}{l}\text { Small } \\
\text { part }\end{array}$ & Walk & $\begin{array}{l}\text { Mixed use centres } \\
\text { Air rights development } \\
\text { Urban infill }\end{array}$ \\
\hline Curitiba, Brazil & BRT & Most & Walk & $\begin{array}{l}\text { "Trinary" Road System } \\
\text { Mixed Use, High Density }\end{array}$ \\
\hline Hong Kong & HRT & Most & Walk & $\begin{array}{l}\text { Transit \& Property } \\
\text { Development Model }\end{array}$ \\
\hline $\begin{array}{l}\emptyset \text { restad New Town } \\
\text { Copenhagen }\end{array}$ & $\begin{array}{l}\text { LRT } \\
\text { mini-metro }\end{array}$ & Part & $\begin{array}{l}\text { Bike, Walk } \\
\text { Bus, HRT }\end{array}$ & $\begin{array}{l}\text { Reclaimed } \\
\text { Mixed Use }\end{array}$ \\
\hline Ottawa, Canada & BRT & $\begin{array}{l}\text { Small } \\
\text { part }\end{array}$ & Walk & $\begin{array}{l}\text { Mixed Use, High Density } \\
\text { walkable \& aesthetic } \\
\text { streetscapes }\end{array}$ \\
\hline Seoul, South Korea & HRT & Most & Walk & $\begin{array}{l}\text { High Density Housing } \\
\text { Digital Media City }\end{array}$ \\
\hline Singapore & HRT & Most & Walk & $\begin{array}{l}\text { High Density Housing } \\
\text { Media 21; Fusion Media }\end{array}$ \\
\hline
\end{tabular}

